University of Warwick institutional repository: http://go.warwick.ac.uk/wrap

This paper is made available online in accordance with publisher policies. Please scroll down to view the document itself. Please refer to the repository record for this item and our policy information available from the repository home page for further information.

To see the final version of this paper please visit the publisher's website. Access to the published version may require a subscription.

Author(s): Capp, Bernard

Article Title: A door of hope Re-opened: The Fifth Monarchy, King Charles and King Jesus

Year of publication: 2008

Link to published version: http://dx.doi.org/10.1111/j.1467-

9809.2008.00699.x 
Author: Bernard Capp

Dept of History, University of Warwick, Coventry CV4 7AL, UK

MA, DPhil, FBA

b.s.capp@warwick.ac.uk

tel (+) 02476523410

\title{
A Door of Hope Re-opened: the Fifth Monarchy, King Charles and King Jesus
}

\author{
Abstract \\ A Door of Hope was the manifesto of the Fifth Monarchists' desperate uprising in \\ London in January 1661, a few months after the Restoration of Charles II. While the \\ rising itself is well known, its manifesto has never been examined in detail. Probably \\ based on a sermon to Venner's congregation, it displays a defiant conviction that the \\ Restoration could be understood as part of God's providential plan, the next step towards \\ the imminent kingdom of Christ on earth. But it also reaches out to a much wider \\ constituency, all the supporters of the "Good Old Cause”, offering a programme that \\ might appeal to many radicals. And the author draws on secular, republican discourse to \\ buttress his apocalyptic claims, revealing close links between even the most extreme \\ Fifth Monarchists and wider currents of interregnum radicalism.
}


Key words: Fifth Monarchists; millennium; Good Old Cause; rebellion

The Fifth Monarchist uprising in London in January 1661, led by Thomas Venner and members of his Swan Alley congregation, was long remembered as the last, desperate outburst of the revolutionary fervour generated by the English Revolution. ${ }^{1}$ Over forty people were killed in street fighting, with many others wounded. When it was all over Samuel Pepys reflected that it was "A thing that never was heard of, that so few men should dare and do so much mischief”. ${ }^{2}$ Venner was subsequently hanged, drawn and quartered, and twelve of his surviving companions were also put to death. Plotting against the restored Stuarts was to remain endemic for years, as the work of Richard Greaves has established, ${ }^{3}$ but the rebels’ manifesto stands as a final, defiant assertion and exposition of radical dreams. While the rising itself is noted in most histories of the Restoration, its manifesto has been generally overlooked. Yet A Door of Hope: or a Call and Declaration for the gathering together of the first ripe Fruits unto the Standard of our Lord, King Jesus contains much of interest, and some surprises, amidst its fiery millennial rhetoric. This article makes some amends for past neglect. ${ }^{4}$

The radical movements of the English Revolution are no longer a fashionable subject for historical research. Even thirty years ago, when academic and public interest was at its peak, the Fifth Monarchists occupied a marginal position. They barely figured in 
Christopher Hill’s influential The World Turned Upside Down (1972), which discussed Levellers, Diggers, Ranters and Quakers in some detail. Though revolutionary in their total rejection of the political, social and ecclesiastical structures of their age, the Fifth Monarchists espoused a theocratic agenda which did not sit comfortably within Hill’s picture of egalitarian radicals striving for "something far nobler" than either their own world or indeed ours. ${ }^{5}$ For their part, most undergraduates found the Fifth Monarchist mentality almost impossible to relate to the modern age. In that respect, at least, times have changed: the rise of fundamentalist, theocratic Islamist movements in Iran, Afghanistan and Iraq has made such ideologies all too familiar today, a development paralleled by the emergence of extremist groups within the Jewish and Christian faiths. Paradoxically, it is the Fifth Monarchists rather than communist Diggers who now appear most "relevant" to our age.

The Fifth Monarchists emerged in the years immediately following the king's execution in January 1649, fired by hopes that such an unprecedented event proved the millennium was at hand, but equally by fears that the Rump and New Model Army had no intention to assist in its birth. Some initially pinned their hopes on Oliver Cromwell as a second Moses who would lead the people into the promised land, but with the fall of the Nominated (“Barebone’s”) Parliament in December 1653, they agreed in viewing Cromwell as an apostate and his regime as part of the Babylonian tyranny. ${ }^{6}$ It was thus for the "saints" themselves to act as God's instruments. In their first years, to 1653, the Fifth Monarchists had acted as a pressure-group, agitating against the Rump and then pressing more radical policies on Barebone's Parliament; thereafter they adopted a 
position of outright opposition to the Protectorate. The movement is best characterised as a radical alliance, rather than as a sect or denomination. Its supporters shared a core belief in their duty to bear witness against an illegal and ungodly regime, and thereby to promote the kingdom of Christ, which they viewed as imminent and inevitable despite the apostasy of so many. Beyond that we find a striking diversity of opinion, with individuals and congregations retaining earlier or parallel identities and convictions as Congregationalists or Baptists (whether Particular, i.e. Calvinist, General, or SeventhDay). While they succeeded in developing a loose national network, there was often friction over these differences and even more over the nature of political resistance. Was it sufficient simply to repudiate the regime, verbally or in print? Or was it their duty to take up arms, either relying on divine protection in the face of seemingly impossible odds, or actively seeking allies? The collapse of the Protectorate in 1659 raised their hopes once more, but these hopes were quickly dashed as the Commonwealth disintegrated and Charles II was restored to his throne with apparently miraculous speed and ease.

In one of his later works, The Experience of Defeat (1984), Christopher Hill explored how radicals came to terms with the total collapse of the Revolution and their apparent abandonment by God. For those who thought within a providentialist mind-set, as most radicals did, these were terrible days; for the divine providences of the 1640s, the overthrow of the Bishops, King and Lords, were all reversed. Did that mean their entire reading of the preceding twenty years had been wrong? Or, an equally dismal thought, that God had turned his back on an ungrateful and self-seeking people? In the months 
following the Restoration the most radical Fifth Monarchists firmly rejected any such interpretation of events. The congregation meeting in Swan Alley, off Coleman Street (only a stone's throw from London's Guildhall), had been the most militant group throughout the Cromwellian Protectorate. Its leader, the cooper Thomas Venner, had emigrated to New England in the late 1630s and had spent over a decade in Salem and Boston before returning to England in 1651 to help build Zion at home. When Cromwell's Protectorate "betrayed" that cause, Venner was prominent among those who sought to build a militant alliance against the regime, by drawing in radical Baptists and disgruntled republican army and naval officers. And when these negotiations failed, he and his followers attempted their own uprising, in April 1657. But the plotters had been infiltrated by Secretary Thurloe's agents, and many of the would-be rebels were arrested as they arrived at their rendezvous. Remarkably, their lives were spared. Though held in the Tower Venner was never brought to trial, and was released from prison in 1659 following the fall of the Protectorate. ${ }^{7}$ Few rebels in the seventeenth century enjoyed an opportunity to try again.

A Door of Hope is a small quarto pamphlet of two sheets and only 16 pages.

Understandably, the title-page affords no clue to the identity of author or printer, and it was presumably disseminated by hand. Venner himself may have penned it, though a more likely candidate is his son-in-law William Medley, who had subscribed the manifesto of the 1657 rebellion, A Standard Set Up, as "scribe". ${ }^{8}$ While the two tracts share the same core message, justifying armed insurrection to advance the kingdom of Christ on earth, they are very different in style and flavour. A Door of Hope is an 
impassioned tirade, probably reworked from an inflammatory sermon to the Swan Alley faithful. ${ }^{9}$ Several passages appear clearly designed to work the audience to a frenzy, with rhetorical questions- more than twenty in all- inviting its vocal response. In one such passage the author/preacher insists that the Restoration had been engineered by treachery:

And now to suffer all these things, and lose our Birth-rights, and to entail Persecution, Slavery, Popery, and Idolatry, to our Posterities for ever ... is grievous; but to suffer them from the Cavaliers, an old, beaten Enemy, and that without striking a blow, or bleeding in the Field for that which is much better then our Lives (for as a Romane could say, There is no necessity that I should live, but there is a necessity that Rome should be relieved) is the Aggravation. For how did this old Enemy come in? did he beat us in the Field? did he win it with his sword? is our Cause lost? or is our God dead? no! how then? Why, by lies ... by hellish plots and contrivement (A Door, 8).

We can picture the impassioned preacher and the roars of his audience. So could the author of a fierce attack on the rising and its manifesto, who observed that "'tis more then probable, that Venner's Preachment blew them into so sudden Action”. ${ }^{10}$ But the passage is interesting on other grounds too: we note the allusions to birth-rights, and the linkage of godly zeal with the virtue of the anonymous Roman (perhaps Horace). While it is highly unlikely that Thomas Hobbes ever read A Door of Hope, this passage would have reinforced his conviction that the classics could breed dangerously subversive ideas. ${ }^{11}$ The tract repeatedly marries millennial fervour with secular principles and concerns, 
drawing on ideas and information absorbed from contemporary political ideas, newspapers and a grammar-school education.

The last five pages of the text are very different in style and character. It was not unusual in this period for printed sermons to carry other material as appendices, as seems to be the case here. ${ }^{12}$ Headed "Some choice Teachings and Hints", this section grapples with the biblical prophecy of the two witnesses described in Rev.11, offering an interpretation that draws heavily on the commentaries of Joseph Mede, the Cambridge theologian, John Tillinghast, a Fifth Monarchist minister and biblical commentator, and Clavis Apocalyptica, a German text translated into English by Samuel Hartlib in 1651. The witnesses are identified, conventionally enough, as true Christian believers, faithful down the ages in the face of persecution and destined to play a crucial role in the final stages of God's providential design. But the exposition builds to a dramatic and highly unconventional conclusion, directly related to the preceding call to arms.

A Door of Hope begins in typically pugnacious style by defending the execution of Charles I as a murderer, tyrant and traitor, citing in support the bellicose parliamentary declaration of 11 February 1648, which had defended the Commons' vote of No Further Addresses by depicting the entire reign of Charles I as a conspiracy to impose tyranny and popery on England. ${ }^{13}$ A Door also expressed delight that even "Germany was not without a witness (that Learned and Judicious Author of Clavis Apocalyptica) to the Righteousnesse of that Sentence” (1). But the author readily acknowledges that God has chosen to permit the restoration of the late king's son, identified with scant respect as " $C$. 
S” (i.e. Charles Stuart), a "strange Providence, whereat most are confounded".

Interpreting divine providence was central to the faith of Fifth Monarchists, as of all religious radicals. While most radicals came to the regretful conclusion that God had abandoned the English for their manifold sins and shortcomings, A Door offered a very different interpretation. God had permitted the apparent ruination of the godly cause only in order to test the truly faithful, "to punish and spue out of his mouth a Lukewarm People”, and to make the ensuing vindication of his cause all the more glorious. Though the profane might triumph in the return of Charles Stuart, the godly rejoiced to see them "brought as Foxes into the Snare”. The Restoration marked simply the latest stage in God's unfolding design, and the godly were accordingly untroubled by the apparent triumph of the cavaliers at "the coming in of their poor wretched King, at whom ... we laugh, and have them in derision” (1-2). That echoed Psalm 2:4, where the godly laugh at foolish and proud kings who set themselves against the Lord. The writer was convinced that biblical parallels offered both comfort and reassurance to those dismayed by England's present plight. He cited Jer. 22:7-8 to remind them how the Lord had led the Jews out of captivity, and he placed Charles II in a line of persecuting tyrants stretching from Nimrod through Nebuchadnezzar to show how often God had raised up kings only in order to throw them down (1-2). Providence, he noted, had been leading the "Protestant Cause" to similar apparent ruination throughout Europe. The godly were being persecuted in France, Savoy, Bohemia and Poland, while the deaths in 1660 of the king of Sweden (Charles X) and the Prince of Transylvania (György Rákóczi, mortally wounded in battle against the Ottoman Turks) foreshadowed further oppressions abroad 
as in England (7). God's glory and the triumph of the saints would be all the greater when their persecutors were swept aside.

It was now the duty of true believers, the "two witnesses”, to further God's providential design. Giving thanks for having survived uncorrupted during the "wicked Apostacy of O.C." (Oliver Cromwell), they would now "gird on a Sword for Christ” and dedicate their lives and estates to “the Lord King Jesus” as soldiers in the Lamb’s army. And their mission would extend far beyond establishing godly rule in England; they vowed to "go on to France, Spain, Germany, and Rome, to destroy the Beast and Whore ... to bring not only these but all the Nations to the Subjection of Christ that the Kingdome may be the Lords” (3).

To undertake such a design, they would clearly need to draw in many others. A Door is deliberately inclusive, appealing repeatedly to all godly "brethren”, “saints” and “witnesses”. The Fifth Monarchists themselves are never mentioned as such by name. ${ }^{14}$ Instead the author anticipated the glorious day when power would pass to the "Saints (without respect had to any particular form or judgement)” (9). Going further, he urged all those dismayed by the fall of the Commonwealth who thus "own at least the negative part of our Cause" to join in the crusade, for "this good and wholesome Principle of Christs Government is so large, that it involves every honest Interest”; and "whoso hath a heart to rise up for God against the Pope, his Bishops, and Hierarchy, and against these Cavaliers, whose wickedness it is not fit to name, who have already polluted the Land as venemous and unclean Creatures; here is a call and opportunity for them” (4). Even 
uncommitted readers could rest assured they had no reason to oppose the uprising, for they had nothing to fear; the saints respected private property, their army would be rigorously disciplined, its soldiers regularly paid, and no harm would befall any except those who resisted by force (10).

In seeking to draw in a wider body of potential supporters the author was of course acknowledging political and military realities. His strategy was far from novel, however; throughout the Protectorate the Fifth Monarchists had sought to build alliances with disaffected Baptists, republicans, and army and naval officers. ${ }^{15}$ Vavasor Powell's $A$ Word for God (1655), a Fifth Monarchist petition from Wales, had championed "the advancement of Christ's kingdom”, “the privileges of parliament” and "the liberty of the subjects” within the space of a single sentence. ${ }^{16}$ Venner and his followers had been at the heart of an attempt to build an anti-Cromwellian alliance in 1655-6, during which Sir Henry Vane's A Healing Question had been mooted as the possible basis for a common platform. ${ }^{17}$ The preacher John Rogers had responded to the failure of Venner's first rising by instituting a series of weekly meetings in London between representatives of different congregations (including Venner's), hoping to reach out once more beyond the Fifth Monarchists’ own ranks. Rogers indeed was soon urging a union between the godly and the Commonwealth party, taking Sir Henry Vane as his guide and inspiration. ${ }^{18}$ And as the Protectorate stumbled early in 1659, radicals urging the promotion of the "Good Old Cause” frequently drew on both millenarian and republican ideology. ${ }^{19}$ The Cause of God, and of these Nations, an anonymous tract published early in March 1659, identified godly rule and civil liberty as twin causes which must advance hand in hand. "The Cause 
of God” naturally took priority, he explained, but it incorporated the cause of secular freedom, and "embraces in its Arms and bosome, the Natural Rights and Liberties of men”. ${ }^{20}$ Early in May, with the Protectorate now swept away, Christopher Feake, a leading Fifth Monarchist preacher, urged all "worthy Patriots” to rally to the "Good Old Cause"; and ended his history of the preceding twenty years of upheaval by identifying the republican Commonwealthsmen and Fifth Monarchists as the only "honest”, "public” interests in a world of private, sectional greed. All faithful men should join in the work of advancing Christ’s kingdom, he wrote; even "Brethren of the Classical-way” (Presbyterians) would be welcome, provided they were modest and sober, not of a "pert, imposing Disposition”. ${ }^{21}$ Livewell Chapman, the leading publisher of Fifth Monarchist tracts, was equally active in 1659 producing secular, republican interpretations of the Good Old Cause. ${ }^{22}$ The rising of January 1661 is rightly seen as a desperate venture by Fifth Monarchist extremists, but the rebels themselves were pursuing a well-established strategy designed to galvanise all supporters of the Good Old Cause.

In reaching out to this wider constituency A Door accordingly shifts repeatedly between the rhetoric of millennial fundamentalism and secular, republican arguments. A sustained rant against prelacy, common-prayer, organs, surplices, lawn sleeves, hoods, altars, bowing, kneeling “and such whorish trash and Trinkery” is followed by a far more sober passage promising honest government with social, economic and legal reforms, and pledging that "whatsoever can be named of a common or publick good, we mean by the Kingdome of Christ, in the Government of the Common-wealth” (4-5). But the dominant religious strain then quickly reappears, with a bitter tirade against the moral decadence of 
Restoration England, and "the open profaneness that rages in our streets". The author exclaims at the "hellish blasphemy" of men "drinking healths to the confusion of Zion, and her King (daring the most high [Christ] to his face), and if he be her King, let him come and save her” (5). Such evils now abounded:

how hath the greatest sins, Swearing, Drunkenness, Sabbath-breaking, Whoredome, Pride, Lasciviousness, Stage-playes, Blasphemy, Superstition, Idolatry been propagated and countenanced since their coming in, as a new life given to the slain Serpent (5).

Coming from an author who had detested the Cromwellian regime, the passage offers striking testimony to the cultural revolution that had accompanied the Restoration. Such profanities were incompatible with the values of King Jesus, he continued, and since their perpetrators were the champions of the restored monarchy it followed "that the $K$. [King] is a profest Enemy, a Rebel and Traytor to Christ” (5). And these evils were compounded by the rage of old "Malignants", free once more to persecute the godly "under the notion of Fanaticks” (6).

Far greater troubles lay ahead, the author warned, presenting chilling evidence of "the design of a Butchery and Massacre of the honest Party" by "the old cursed Popish Party" (6). The fear of popery, so potent in 1640-2 in the wake of Laudian innovations and the Irish Rebellion, was once again a real and plausible menace, and A Door exploited it to the full. "Episcopacy and Common Prayer is but the door to something worse", it warned, 
identifying a "Grand Conspiracy” to root out Protestantism altogether. In support it pointed to the papists swarming around Westminster, some of them guilty of the Irish massacre, the return of the old queen, Henrietta Maria, “who is said to hate an English Protestant so, that she cannot endure the sight of them”, "multitudes of the cruel bloody Spaniards” attending the Spanish ambassador, and similar ruffians surrounding Prince Rupert. All this pointed to a bloody design in which the pope, king of Spain and Habsburg Emperor all had a hand: "We know the Papists Principle; No faith is to be kept with Hereticks: let us remember France and Ireland; and not forget Piedmont, whose wounds bleed yet fresh in our memories. They are making our Throats bare to the Knives of their Butchers” (6-7). ${ }^{23}$

A Door was thus justifying a war both "offensive” and "defensive”, in which the saints would establish Christ's kingdom on earth and thereby preserve the people from popery, massacre and oppression. Charles II was simultaneously a tyrant and a traitor to the true King, Jesus, and the godly were freed from any obligation to obey him. Drawing for support on the secular language of contract theory, it explained that the state could have no claim to their allegiance for it offered them no protection, the fundamental purpose of all human government:

And these men themselves have set us free from the Bonds of Subjection; for we have no benefit by the Government of this bloody Family, neither are we comprehended within the Verge of their Protection: Wherefore they cannot justly 
challenge any Obedience from us by the Law of Nature or Nations: For a man is not bound to pay him Subjection who seeks his Destruction (8).

The "Law of Nature and Nations" was generally interpreted as morally informed reason enshrining an inalienable right to self-preservation. Widely invoked in the 1640s against an allegedly tyrannical king, it now justified the godly in taking up arms against the restored Stuart monarchy which threatened their destruction (7). Implicit within it was the principle of popular sovereignty. Parliamentary apologists since Henry Parker had argued that sovereignty was fundamentally rooted in the people, who had set up kings to protect them and could legitimately resist any king who betrayed that trust. Extending the argument, the Leveller Richard Overton argued in 1647 that the people were equally free to repudiate their allegiance to a now “degenerate” Parliament which similarly sought their destruction. ${ }^{24}$ The concept of a social contract was also central to the classical republican thinking that flourished in the 1650s alongside political languages derived from the Bible and common law. ${ }^{25}$ While some religious radicals scorned the secular language of republicanism, we have seen that others readily combined the two ideals.

It comes as no surprise, however, to find A Door's ensuing peroration reverting to providential theory, couched in the most extreme terms:

And this is our joy, that our God has bound himself ... to appear for his People: And if God should not appear for the poor Remnant of Jacob, but suffer them ... to fall before Papists, and Cavaliers, and prophane, drunken, damning, swearing, 
Idolatrous, Adulterous, wicked and ungodly men; and should suffer the Cause of the Papists, of the bloody Family of the Stuarts, of the old, bloody, Popish, wicked Gentry of the Nation, of the drunken, dumb, Popish, scandalous Clergy, to get the upper hand of his own Cause, and should suffer all our Reformation to be lost, then what would become of his great Name? It was because he could not bring them into the good Land (will the Enemy say) that he has destroyed them in the Wilderness (8).

Or in short: the rebellion must succeed, for failure would irrevocably destroy God's own credit and credibility. An astonishingly presumptuous reading of divine providence, this would have struck most contemporaries as horrid blasphemy. But the rebels were confident in their interpretation of biblical prophecy and their own duty, and happy to sacrifice their lives in advancing God's work, if need be; for "certainly if we be deceived, God has deceived us" for his own inscrutable ends (an echo of the prophet Jeremiah's cry, Jer. 21:7) (8).

The final three pages of the main text outline the rebels' programme, appealing to "our Brethren” in London and every county to join in their work. The author begins by repudiating any national parochial church system, damned as antichristian even in its purest form, under Cromwell's Triers. The true gathered churches, "purged and purified", will blossom and grow with a multitude of new converts (9). Godly magistrates will rule the land, enforcing the laws of God enshrined in scripture (the Mosaic laws) (9-10). "Civill Liberty, and Rights of men (which with every mans Propertie we assert)", will 
flourish in this new order (10). To prepare the way, antichristian forms will be swept aside. Taxes, tithes, excise and customs will be removed, "as far as Oppressive and unlawfull”, and

slavish tenures of Land, Oppressions of Landlords, Monarchy and Lordship as well in Church as State; so also in Cities, Societies and Families, wherein the Rights of younger Brethren will be vindicated according to Law, ... and the Nimrod spirit and Monopolies of elder Brethren (unto whom as Kings in the Family, the younger Brethren are Slaves and Subjects, which is one grand branch of Tyranny, and Interest of Monarchy) pulled down, whose Interest nevertheless, by right of Primogeniture, is asserted according to the Kings Law, to wit twofold: For the ballance of Lands must be adequate to the Government of the Commonwealth (9-10).

This is a remarkable passage, despite its highly compressed language. It recalls the Levellers' condemnation of oligarchy and monopoly in the government of London and its Companies, while the imagery of the older/younger brother, applied to the entire edifice of socio-economic privilege as well as the family, echoes Gerrard Winstanley. So, of course, do the branches of the tree of tyranny, or kingly power, the central motif of Winstanley's A New Years Gift (1650). ${ }^{26}$ By contrast, the author is also familiar with the political language of private and public interests, while the linkage between patterns of land-ownership and forms of government suggests he was familiar with James Harrington's Oceana, or at least its central ideas. It provides another pointer to the 
connections between even the most extreme Fifth Monarchists and more "mainstream" republican currents. Livewell Chapman, the Fifth Monarchists’ main publisher, was also the publisher of Oceana. John Rogers provides another obvious connection, engaging in print with Harrington in 1659 but also closely associated with Venner's congregation. ${ }^{27}$

This section of A Door was building upon an earlier passage that outlined the rebels' reforming agenda. There the author explained that by "a well ordered Common-wealth" he meant government by men of integrity, dispensing speedy and impartial justice based on the "wholesome" Law of God, and bringing relief to orphans and widows. He did not elaborate how such men would be chosen, but offered rather more detail on the legal reforms proposed. The law of debt would be transformed on the basis of both justice and mercy, bringing relief to creditors and debtors alike, unlike the existing practice of indefinite imprisonment for debt. He urged that thieves no longer be hanged "but that restitution be made according to the [Mosaic] Law, and the Malefactor sold, or made to work out his redemption in some house of Correction, which in few years would make us fewer Thieves than a thousand Gallowses”. The poor would be set to work, and protection offered to sustain English manufactures and trade, with a ban on the export of unfinished leather and fuller's earth (used in the bleaching of cloth). Timber supplies would be protected too (4-5). The passage gives only a few glimpses of the future kingdom of Christ on earth- the author was more concerned with the cosmic battle that must precede it- but we have enough to see that its arrangements would be closely attuned to the practical concerns of London tradesmen and artisans. We note too that it focuses on those aspects of law reform most likely to enjoy broad support, while passing 
silently over the draconian penalties for moral offences also enshrined in the Mosaic code. $^{28}$

A Standard Set Up, the manifesto of the abortive 1657 rising, had gone into rather more detail on several of these points. It proposed a form of government modelled on the old Jewish sanhedrin, a council comprising men of integrity and virtue, which had also inspired the Nominated (or “Barebone’s”) Parliament of 1653. This body would control the armed forces, but would have no authority to impose a state church, nor to violate "any of the Foundations of Common-Right, and Freedome, which are, or shall be agreed upon”, a proviso recalling the fundamental rights enshrined in the Levellers’ “Agreements of the People”. Its members would represent the whole nation but be chosen by "the Saints" alone, and would serve for an indefinite period subject to confirmation or dismissal by the electors at the end of each year, a variant of Leveller plans for annual parliaments. Courts would be held in each county, four times a year, to deal with major crimes, with judges sitting monthly in every market-town to handle civil suits and lesser criminal cases. Men would plead their own causes, with state-appointed counsel assisting in complex cases. Impressment into the army would be forbidden, tithes and excise abolished, and taxation strictly curtailed. Oppressive conditions applying to copyhold and customary tenures of land would be “clean removed”, sweeping away heriots, fines and other dues. ${ }^{29}$ Most of these proposals were probably still supported by the 1661 rebels. 
The main text of $A$ Door ends with a rallying call to all public-spirited readers to join the great work, and an assurance that truly penitent members of the "old [Cromwellian] Army, which God hath laid aside”, would be welcomed too. But it acknowledged that “young Converts ... are like to be the choicest instruments in this Work” (11). One of Secretary Thurloe’s informants, reporting on a meeting back in 1656, had noted that young people, many of them apprentices, dominated the Swan Alley assembly, and that the preacher's inflammatory rhetoric had been explicitly targeted at them. ${ }^{30}$ Its focus on glory, heroic adventure and self-sacrifice may well have appealed to youthful idealism.

As we would expect, A Door is steeped throughout in biblical imagery, buttressed with direct citations. Revelation dominates the main text, as well as the appendix, with fourteen citations. All but two of the other twenty citations are from the Old Testament, drawn mainly from Psalms and Jeremiah, lamenting the sins and sufferings of God's people while holding out the promise of certain deliverance. There was comfort too in Isa. 59:19, quoted on the opening page, which tells how God will allow the enemy to "come in like a flood". The audience would not need to be reminded how the verse goes on to promise that "the Lord shall lift up a standard against him". That text, echoed in Isa. 62:10, had inspired the manifesto of the 1657 rising, A Standard Set $U p$, and inspired A Door itself, which carries the sub-title A Call and Declaration for the gathering together of the first ripe Fruits unto the Standard of our Lord King Jesus. Nor would the audience need to be given a scriptural reference for the familiar millenarian promise (from Psalm 149) that the saints would soon be given the power to "binde their Kings in Chains, and their Nobles in Fetters of Iron” (4). 
The final section of A Door, in effect a "scholarly" appendix, is markedly different in style. It offers a relatively sober exposition of the prophecy of the two witnesses in Rev. 11, identified as true Christians down the ages who have remained faithful unto death, and now lie dead (for three and a half days) until their resurrection. The object is to prove this resurrection imminent. The prophecy is linked to other prophecies of persecution, notably the 1290 days in Dan. 12:11, and 1260 days or 42 months of Rev.11. Drawing on the biblical scholarship of Mede, Tillinghast and Clavis Apocalyptica, the author concludes that these prophetic times elapsed in 1656; which, by adding the three and a half days (or years) of the witnesses lying dead, "brings us to this very year 1660” (14). (In the seventeenth-century calendar the new year began on 25 March, and Venner's rising therefore took place in 1660.) Evidence is then adduced to substantiate this interpretation. For three of the three and a half years an outwardly pious power would restrain the Beast from his savage blood-lust, "a moderate civil kinde of People, pretending to Reformation in matters of State". These people would then be swept aside as their old conquered enemies triumphed once more, unleashing a new age of persecution. The former party were easily identified as the Cromwellians, the latter as "the old carnall, Cavalier Popish Party" who had returned "to over-throw our Reformation again with Popery, Prelacy and Superstition”. But their time will be short: "For it seems to us, that the Cavaliers from their first coming in, have but about six moneths time” (14). The analysis then considers the role of Cromwell. Down the centuries, from the time of the Emperor Julian, persecutors had destroyed the bodies of true believers, but their spirits had remained unbroken. By contrast, Cromwell's cunning 
had killed the witnesses "civilly and spiritually", a far more terrible death, by frustrating their "Finishing-Testimony", explained as the attempt to proclaim and establish the kingdom of Christ on earth (15-16). These lines were probably penned late in 1660, with the writer perhaps counting the three and a half years of the witnesses' death from April 1657, the date of the Fifth Monarchists' first abortive uprising. While contemporaries would have ridiculed any notion of the Swan Alley congregation being foreshadowed in scripture, the writer insisted that Cromwell himself had been disconcerted by the possibility:

about a year and a half before his death [i.e. about April 1657], this Prophecy of the Witnesses seemed to trouble him very much; and he was very earnest with two of us, to know what we thought of the Witnesses, the which he seemed to speak with a convinced guilty minde, and some kinde of regret (16).

Cromwell had indeed interrogated the leading conspirators in April 1657 and, though we can dismiss his alleged feelings of guilt, he shared the Fifth Monarchists’ longing to decipher God's providence and his own "generation-work". ${ }^{31}$ The prisoners may well have discerned a certain ruefulness as he compared his uncertainty with their own sublime self-confidence.

A Door ends by insisting that the biblical prophecies must refer to England, 'the very Stage of Action' in the world over the preceding twenty years. It noted that even foreign writers had recognised that the unparalleled upheavals foreshadowed the approaching 
end, a claim supported by references to Clavis Apocalyptica and Menassah ben Israel's The Hope of Israel (1652). Menassah had appealed to Parliament, and later to Cromwell, to re-admit Jews to England, a proposal of great interest to the Fifth Monarchists (as to Cromwell), for the conversion of the Jews was widely regarded as another of the signs heralding the apocalypse, and re-admission might well pave the way. England was thus at the very crux of unfolding European events. If an equally strong case could be advanced for Germany, A Door graciously conceded, “then we will consider further”. But the signs pointed clearly to England, and "In all probability, the great Day of the Witnesses Rise, will be in this present Year, 1660. AMEN” (16). ${ }^{32}$

It appears rather surprising now to find this relatively measured and dispassionate piece of biblical exegesis attached to a fiery, sometimes almost hysterical call to arms. The author is at pains throughout to stress how frequently his interpretations follow those of eminent scholars, "worthy famous men” such as Mede, Tillinghast, the 'German Author" [of Clavis], "and other Authors of no small authority" (12). The textual analysis is punctuated by repeated references to such authorities: “so Mede”, “so Tilling.”, “M. Tillinghasts very words" (13-14). The whole analysis is "Humbly submitted to Saints Consideration”, and its final conclusions “we leave to sober and judicious men to judge” $(12,16)$. In the wake of the Restoration, the Fifth Monarchists had to contend with a general conviction among radicals that God had turned his back on them, and that millenarian optimism had been sadly misplaced. As the manifesto’s title suggests, they were seeking to open a door that most regarded as firmly shut. To convince the Fifth Monarchists themselves, and still more to draw in outsiders, it was essential to 
demonstrate that the rebels' readings of both providence and scripture were well founded. The discussions between Fifth Monarchists and other anti-Cromwellian dissidents in 1656 had similarly included a consideration of both issues. On that occasion Venner's group had failed to convince even other Fifth Monarchist groups; some had judged them too rash, eager for violence without clear biblical sanction and hence doomed to destruction. "Some choice Teachings" thus sought to convince the godly reader that the Fifth Monarchists’ militant zeal rested on a sober analysis of scripture, supported by reputable scholars. Even the main text of A Door, for all its fierce rhetoric, repeatedly insisted on the reasonableness of its arguments. Religious radicals generally preferred the guidance of the spirit and scripture to mere human reason, and A Door at one point acknowledged that the godly "go a step above depraved reason, and common understanding” (4). But the author also insists that his argument is "very rational”, cites the "Law of Nature and Nations" as well as scripture, and is at pains to correct popular misconceptions about the kingdom of Christ, "not in scripture and reason, ... as that Christ should immediately appear to head an Army” (4, 6-8).

We do not know how widely A Door was disseminated in the few days between the rising and its suppression. The bookseller and collector George Thomason managed to acquire a copy (undated), the only one now known to survive. ${ }^{34}$ Several pamphleteers rushed to give a narrative of the rising, and two set out to answer A Door itself. Hell broke loose (1661) reprints the first eleven pages of A Door in their entirety, rebutting its claims paragraph by paragraph, and The Phanatiques Creed, or a Door of Safety (dated 15 January1661) also reprints substantial sections. Both authors probably assumed that 
most readers who had heard of and perhaps even witnessed the rising would not have seen its manifesto. Reprinting the text risked giving the rebels new publicity, but also offered a perfect opportunity to smear any opposition to the new regime with the taint of fanaticism. Hell broke loose indeed concludes with satisfaction that the rising, and its manifesto, must spell the total ruin of "that vain Idol, the GOOD OLD CAUSE". ${ }^{35}$ Both authors met the claims of $A$ Door with expressions of horror, outrage, and contempt rather than engaging in detail with its arguments. It was 'Time Lost to oppose Argument against pretended Revelation”, one remarked, ignoring the fact that $A$ Door was based on scriptural exegesis, however contentious. In any case, the prophecies of Daniel and Revelation, and the Number of the Beast, were brushed aside as no more than 'Tedious Fooleries'. ${ }^{36}$ A Door's author was condemned as a rebel, traitor and ignorant fanatic. He was both a dangerous new John of Leyden and an absurd fantasist, a "brave Knight of the Oracle” aping St. George in a crazed mission to rescue the "Holy Sisters” from an imagined dragon. ${ }^{37}$ At the same time, it was deemed necessary to reassure any doubtful readers that Charles II and his bishops could be trusted to protect the Protestant faith from the threat of popery. The Phanatiques Creed also suggested strict new controls on preaching and the press, and the imposition of strict oaths on dissenters that would see defaulters banished twenty miles from the capital. ${ }^{38}$

In the immediate wake of the rising thousands of Baptists, Congregationalists, Quakers and republicans were rounded up and imprisoned by a badly shaken government. Congregationalist and Baptist leaders published hasty repudiations of Venner’s action, while the rising prompted the Quakers to formalise what became known as their "peace 
principle”, a rejection of all force and violence. ${ }^{39}$ But plotting continued, and it should not surprise us that the overlapping religious and secular strands of interregnum radicalism became ever more closely entwined. They had been far apart in 1653, when Cromwell, spurred on by the Fifth Monarchists and their champion Major-General Harrison, had overthrown the Rump and established a "Parliament of Saints". Under the Protectorate, by contrast, republicans and Fifth Monarchists had shared an embittered opposition to the new regime, and they had drawn much closer in 1659 in seeking to revive the "Good Old Cause". Moreover, while proclaiming the rule of the saints, the Fifth Monarchists had always balanced their theocratic fervour with a vision of social harmony and justice once that kingdom was established. A Door of Hope reflects the links as well as the contrasts between the Fifth Monarchist and other radical visions. In the years after 1661 most Fifth Monarchists were gradually reabsorbed among the peaceful Baptists and Congregationalists. But others, including Venner's son Thomas and son-in-law Medley, both of whom survived the rising, found a place within the political opposition and lived long enough to throw in their lot with Shaftesbury, Monmouth and William of Orange. ${ }^{40}$ While such links offer us a glimpse of radical continuities, they underline too how completely the political and religious world had been transformed since the door of hope was slammed in 1661.

Notes

1. For Venner's rising and life see Richard L. Greaves, Deliver Us from Evil: the Radical Underground in Britain, 1660-1663 (Oxford: OUP, 1986), 50-57; The 
Oxford Dictionary of National Biography (Oxford: OUP, 2004, and on-line; henceforth $O D N B$ ), s.n. Venner. On the movement see L. F. Brown, The Political Activities of the Baptists and Fifth Monarchy Men (New York: Burt Franklin,1965; $1^{\text {st }}$ pub. London 1911); P. G. Rogers, The Fifth Monarchy Men (London: OUP, 1966); B. S. Capp, The Fifth Monarchy Men (London: Faber and Faber, 1972). For the wider context see J. F. McGregor and B. Reay (eds.), Radical Religion in the English Revolution (Oxford: OUP, 1984).

2. The Diary of Samuel Pepys, ed. R. C. Latham and W. Matthews (London: Bell and Hyman, 1971-83), ii.10.

3. Greaves, Deliver Us from Evil; idem, Enemies Under His Feet: Radicals and Nonconformists in Britain, 1664-1677 (Stanford, Calif.: Stanford U.P., 1990).

4. There are brief accounts of the policies advocated in A Door and A Standard Set Up in C. Hill, The Experience of Defeat (London: Faber and Faber, 1984), 62-66, and Rogers, 140-43.

5. C Hill, The World Turned Upside Down (Harmondsworth: Penguin, 1972), 384.

6. For a good example see the case of John Rogers: To His Excellency, the Lord Generall Cromwell. A Few Proposals (London, 1653); A Collection of the State Papers of John Thurloe, ed. T. Birch (London, 1742), ii.196, iii.136-7.

7. ODNB, s.n. Venner; Capp, 114-18.

8. Hill ascribes both tracts to Venner: Experience, 63. But Thurloe explicitly denied Venner's authorship of A Standard: see Thurloe, vi.186.

9. On sermons in print see J. Rigney, “'To lye upon a Stationers stall, like a piece of coarse flesh in a Shambles': the sermon, print and the English Civil War”, in L. A. 
Ferrell and P. McCullough (eds.), The English Sermon Revised (Manchester:

Manchester University Press, 2000), 188-207.

10. The Phanatiques Creed (London, 1661), 13.

11. T. Hobbes, Behemoth, ed. F. Tönnies (London: Frank Cass, 1969), 23, 43, 56.

12. Rigney, 193.

13. A Declaration of the Commons in Parliament assembled; expressing their Reasons and Grounds of passing the late Resolutions touching No farther Address or Application to be made to the King (London, 1648).

14. The Fifth Monarchy Men', the name by which they were generally known, was not of their own coinage.

15. Capp, 105-22.

16. Thurloe, iv.382.

17. Thurloe, vi.183. Significantly, Vane’s book was read out at the meeting before its publication, though it proved unacceptable to the more militant Fifth Monarchists. For some discussion of it see Austin Woolrych, Britain in Revolution, 1625-1660 (Oxford: OUP, 2002), 641-2.

18. J. Rogers, A Reviving Word from the Quick and the Dead (London, 1657). On Rogers see $O D N B$.

19. For a good discussion of the "Good Old Cause” pamphlet literature of 1659 see Complete Prose Works of John Milton, vol.7, ed. R. W. Ayers, introd. by Austin Woolrych (New Haven: Yale University Press, 1980), 19-26. 
20. The Cause of God (London, 1659), 29. The author was probably John Rogers or a close associate. The title page carries the same text (Isa. 59:19) that inspired the title of A Standard Set Up and the sub-title of A Door of Hope.

21. C. Feake, A Beam of Light (London, 1659) sig. A3v, 8, 57-8.

22. On Chapman see ODNB; for his output in early 1659 see G. F. Fortescue, ed., Catalogue of the Pamphlets, Books ...Collected by George Thomason, 1640-1661 (London: the British Museum, 1908), ii.223-41.

23. The allusions were to the Massacre of St Bartholomew (1572), the Irish Rebellion of 1641 and the massacre of the Vaudois (Waldenses) by the Duke of Savoy in 1655, which aroused great concern in England.

24. R. Tuck, Natural Rights Theories. Their Origin and Development (Cambridge: CUP, 1979), 143-55; R. Overton, An Appeale from the Degenerate Representative Body the Commons of England assembled at Westminster ... to the Body Represented (London, 1647), reprinted in A. S. P. Woodhouse (ed.), Puritanism and Liberty (London: J. M. Dent, 1974), 323-34.

25. For a survey see Blair Worden, "English Republicanism” in J. H. Burns and M. Goldie (eds.), The Cambridge History of Political Thought, 1450-1700 (Cambridge: CUP, 1991), 443-75.

26. Brian Manning, The English People and the English Revolution (Harmondsworth: Peregrine, 1978), 298-301; G. Winstanley, The Law of Freedom in a Platform (London, 1652), in C. Hill (ed.), Winstanley: The Law of Freedom and other Writings (Harmondsworth: Pelican, 1973), 352-3. 
27. On interest (a central theme in Feake, 1659) see J. A. W. Gunn, Politics and the Public Interest in the Seventeenth Century (London: Routledge and Kegan Paul, 1969). On Harrington: J. Harrington, The Commonwealth of Oceana (London: 1656);

J. Rogers, A Christian Concertation with Mr. Prin, Mr Baxter, Mr Harrington (London, 1659); J. Harrington, A Parallel of the Spirit of the People with the Spirit of Mr Rogers (London, 1659); (J. Rogers), Mr. Harrington's Parallel Unparallel'd (Lonon,1659); Capp, 120.

28. On the Fifth Monarchists’ programme see Capp, chaps. 6-7.

29. A Standard Set Up (London, 1657), 16-20

30. Thurloe, iv.650-1.

31. For Cromwell and providence see B. Worden, "Providence and politics in Cromwellian England”, Past and Present 109 (1986). On 'generation work' see also The Letters and Speeches of Oliver Cromwell, ed. T. Carlyle (London: Chapman and Hall, 1907), ii.38-39, Cromwell to Oliver St. John, 1648; J. Tillinghast, GenerationWorke (London: 1653-4).

32. On Menasseh and readmission see David S. Katz, Philo-Semitism and the Readmission of the Jews to England 1603-1655 (Oxford: Clarendon Press, 1982).

33. Thurloe, vi.163-4.

34. British Library, Thomason Tracts, E764(7).

35. Hell broke loose (London, 1659), 14.

36. Phanatiques Creed, 2-3.

37. Hell broke loose, 5,9.

38. Hell broke loose, 13; Phanatiques Creed, 12-13. 
39. Greaves, 1986, 57-8; W. C. Braithwaite, The Second Period of Quakerism (London: Macmillan, 1921), 9-13.

40. Oxford DNB, s.n. Venner; Capp, 220-1, 255. 